\title{
ZAKON VLAHOM (IUS VALACHICUM) IN THE CHARTERS ISSUED TO SERBIAN MEDIEVAL MONASTERIES AND KANUNS REGARDING VLACHS IN THE EARLY OTTOMAN TAX REGISTERS (DEFTERS $)^{1}$
}

\author{
MiLOŠ LUKOVIĆ
}

\begin{abstract}
The transhumant type of livestock breeding (mostly sheep, sometimes goats) in the Balkans has Old Balkan roots. It was most frequent in the Balkans in the Middle Ages. This type of livestock breeding was pursued by the locals - Vlachs (even before the arrival of the Slavs), as their only professional activity. Over time, it became very popular, being also adopted by the population of Slavic origin. In the Serbian medieval state, as well as in other Balkan Christian states, there were no regulations that would uniformly regulate the position of the Vlachs. Regulations regarding the position of the Vlachs can usually be found in the foundation or donation charters of the monasteries. In the few charters from the first half of $14^{\text {th }}$ century rules regarding the Vlachs were grouped under the common name Zakon Vlahom. Apart from this, common law applied to them as well. In conquering the Christian lands in the Balkans in the $14^{\text {th }}$ and $15^{\text {th }}$ centuries, the Ottoman state initially held certain lands and regions in a vassal status, and the sanjaks were formed following their definite subjugation and the liquidation of the vassal status; within the subjugated lands or regions. After the formation of a particular sanjak a tax list was immediately established, and that is how Ottoman Tax Registers (defters) were created. In each defter of the particular sanjak in the early Ottoman period (second half of the $15^{\text {th }}$ and the beginning of the $16^{\text {th }}$ century) there existed a regulation known as kanun, regulating the duties of the Vlachs. They contained rules and legal traditions of common law, that had existed earlier in the territories of the subjugated Balkan Christian states.
\end{abstract}

Miloš Luković, PhD, senior research, Institute for Balkan Studies of Serbian Academy of Sciences and Arts, Knez Mihailova 35/4, 11000 Belgrade, Serbia, e-mail: miloslukovic@gmail.com

Keywords: transhumance, katun, Middle Ages, Vlachs, Zakon Vlahom, medieval charters to monasteries, defters.

DOI: http://dx.doi.org/10.14746/bp.2015.22.3

\section{INTRODUCTION}

The medieval Serbian state $\left(12^{\text {th }}-15^{\text {th }}\right.$ centuries $)$ was created in the west of the Balkans and gradually expanded towards the east and southeast - towards Thessaloniki and Constantinople.

From the second half of the $12^{\text {th }}$ century until the second half of the $14^{\text {th }}$ century, the Serbian state was ruled by the Nemanjić dynasty. The law administered in it was

${ }^{1}$ This paper was written as part of the realization of project No. 177022, The Traditional Culture of the Serbs Between the East and West (2011-2015), which is financed by the Ministry of Education, Science and Technological Development of the Republic of Serbia. 


\section{Serbia 12th - 14th century}

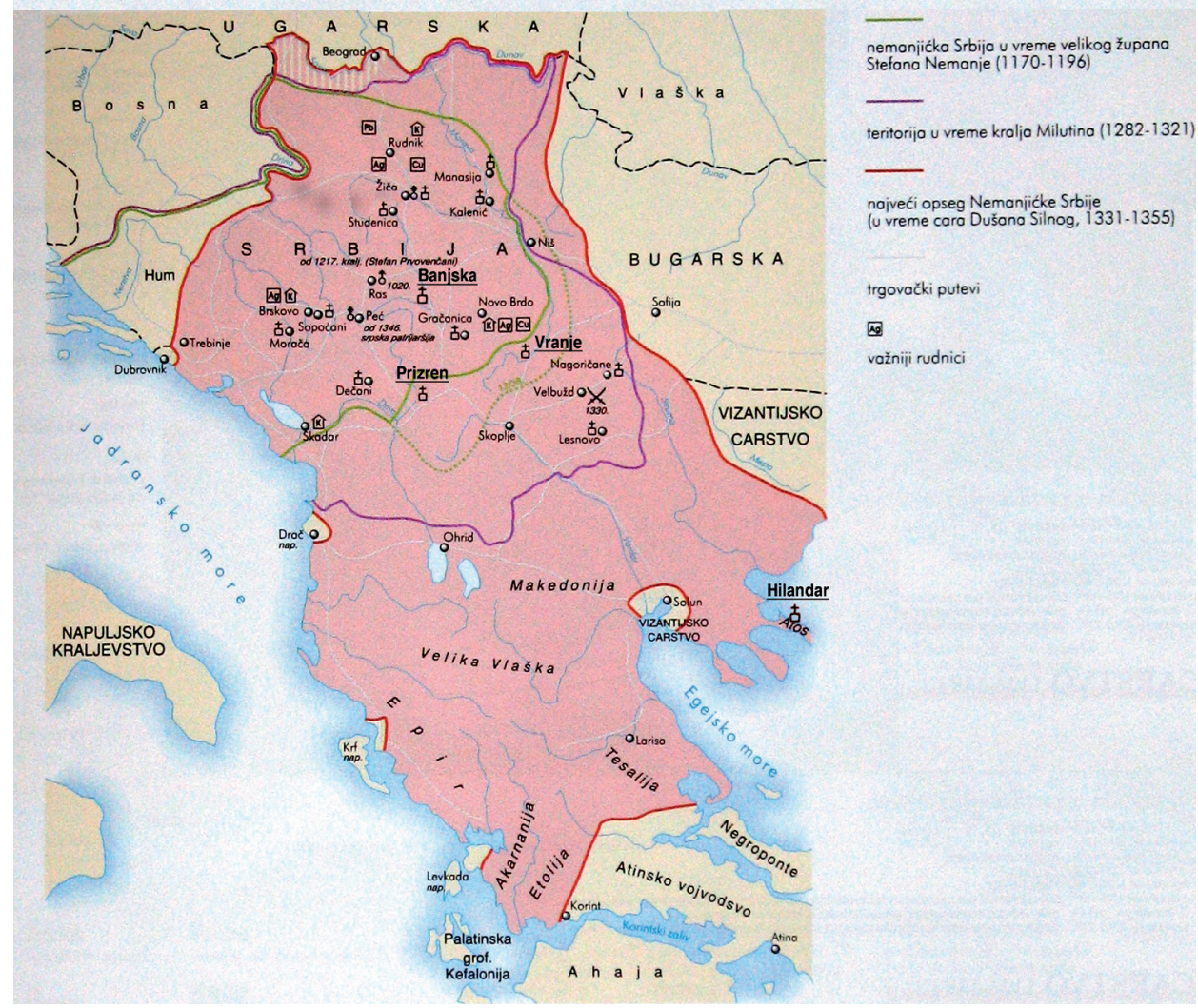

1. Serbia $12^{\text {th }}-15^{\text {th }}$ century (Šehić and Šehić 2007)

in particular feudal law, which was typical of the Middle Ages. ${ }^{2}$ In 1217 the ruler of Serbia bore the title of king, and in 1346 king Stefan Dušan was crowned "emperor of the Serbs and Romans (Greeks)".

However, shortly after the death of emperor Dušan in 1355, his large realm began to disintegrate into several feudal parts which were increasingly independent of his son and heir, emperor Uroš the Fifth (popularly known as Uroš the Weak). With the death of Uroš the Fifth in 1371 the empire ceased to exist even nominally. The independent areas ruled by the feudal lords who bore different titles continued to exist, but in the early 1370's a new power emerged in that part of the Balkans: the Ottomans. In

\footnotetext{
${ }^{2}$ As pointed out by medievalist Srđan Šarkić, see Šarkić 1995, 7.
} 
the following hundred and thirty years the Ottoman Empire gradually subjugated all of what had been the medieval Serbian state. ${ }^{3}$

As medieval Serbia expanded, Vlachs as livestock breeders became increasingly frequently mentioned in written sources. As early as 1921, the Romanian historian Silviu Dragomir compiled 39 medieval Serbian documents where the Vlachs figure, more or less prominently, as livestock breeders. ${ }^{4}$ What may be identified in these documents as a significant feature of the Vlach livestock breeding activity? It is, above all, a distinctive type of livestock breeding and the organization the Vlachs based on it. In other words, there are two notions that should be elucidated here: transhumance and katun. Without them, the legal aspects of the status of Vlachs as livestock breeders can hardly be understood.

\section{TRANSHUMANCE AND KATUN IN THE MIDDLE AGES IN THE BALKANS}

In order to clarify and define the concept of katun, which occurs in medieval sources, we must briefly refer to a special type of livestock breeding in the Balkans. It was the most frequent in the Balkans in the Middle Ages, due to the geographic characteristics of the Balkan Peninsula. ${ }^{5}$

This type of livestock breeding was pursued by the local population - Vlachs (even before the arrival of the Slavs) as their only occupation. ${ }^{6}$ Over time, it became very popular, being also adopted by other populations of Slavic origin. It still exists today, although in a reduced and modified form. ${ }^{7}$ The basic characteristic of this type of

\footnotetext{
${ }^{3}$ For an overview of this gradual subjugation of Serbian medieval states, see esp. Ćirković 1995, $245-258$.

${ }^{4}$ For further details see Dragomir 1921/1921, 279 -299. This paper was reviewed and thus presented to a Yugoslavian audience by the Croatian and Yugoslav romanist and etymologist Petar Skok, see Skok 1928, 305-308.

${ }^{5}$ The boundaries and territories of the Balkan Peninsula were defined by geographer and anthropologist Jovan Cvijić (1865-1927). The Peninsula being surrounded by water on three sides: the Adriatic Sea to the west, the Mediterranean Sea and the Marmara Sea to the south and the Black Sea to the east, Cvijic defined its northern boundary - the River Danube and the River Sava - with more precision. However, he disagreed with what was at the time a widely accepted opinion that the north-western boundary of the Peninsula should be traced "along the valley of the River Kupa, and then in a straight line accross the Dinarides up to Rijeka on the Adriatic coast" because he considered it to be "artificial". Instead, Cvijić claimed that "it would be more natural if the northern border of the Peninsula were to be extended from the confluence of the River Kupa upstream along the valley of the Sava and the Ljubljana basin, all the way up to the connecting point of the Dinarides with the Alps", so that "its western frontier is clearly determined by the River Soča“. For more details see Cvijić 1966, 6, 37-87.

${ }^{6}$ Apart from Vlachs (Vlah / Vlasi), medieval Serbian sources sometimes mention Albanians (Arbanasin / Arbanasi) as livestock breeders. For more details see Šarkić 1995, 40-41.

${ }^{7}$ For a more detailed discussion on the seasonal movement of livestock breeders, see: Cvijić 1966, 215-221, Marcu 1976, 67-70, Dunăre 1976, 189-212, Matkovski 1996, 7-16, Brodel 2001, 83-100, Luković 2012, $150-156,173-178$.
} 


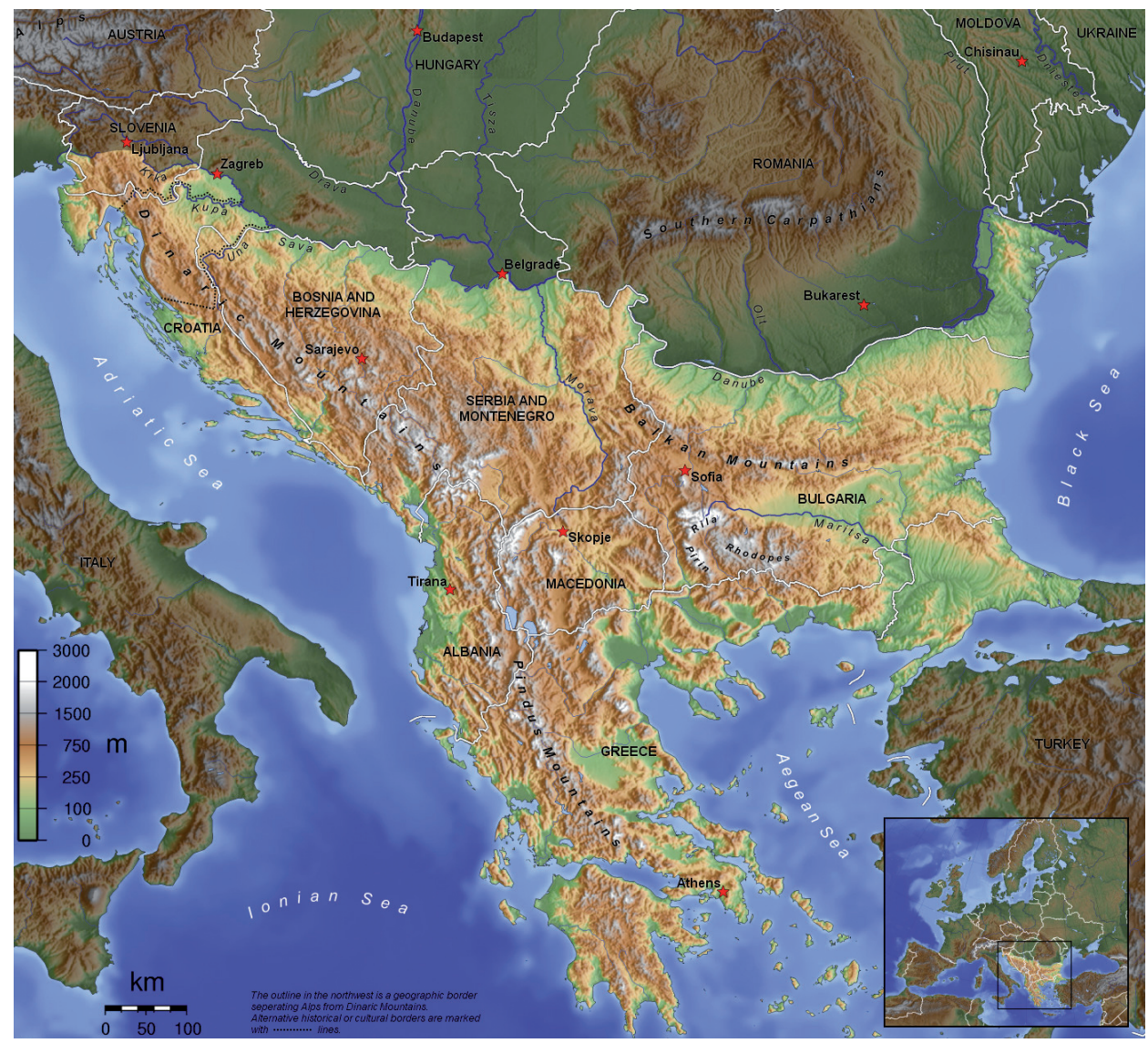

2. The Balkan Peninsula (Cvijić 1966)

livestock breeding is the seasonal movement of shepherds with their livestock (mainly sheep, sometimes goats) between summer pastures in mountains (planine/letišta) and winter pastures in warm coastal lowlands and valleys (zimišta/zimovišta).

Balkan historians, geographers and ethnologists used to define this seasonal movement of livestock breeders in the Balkans as nomadism. However, the modern Romanian legal historian Liviu Marcu, for example, clearly points to the difference between true nomadism and the seasonal movement of livestock breeders in the Balkans. ${ }^{8}$ He emphasizes the fact that the Balkan livestock breeders, during their seasonal movements, had established summer and winter residences, and travelled between them using well-trodden routes. This still applies today, although the season-

${ }^{8}$ Liviu Marcu discussed this issue extensively at the international conference on contemporary legislation policies and customary law pertaining to the seasonal movements of livestock breeders in southeastern Europe, in Belgrade, 1975. See Marcu 1976, 67-81. 


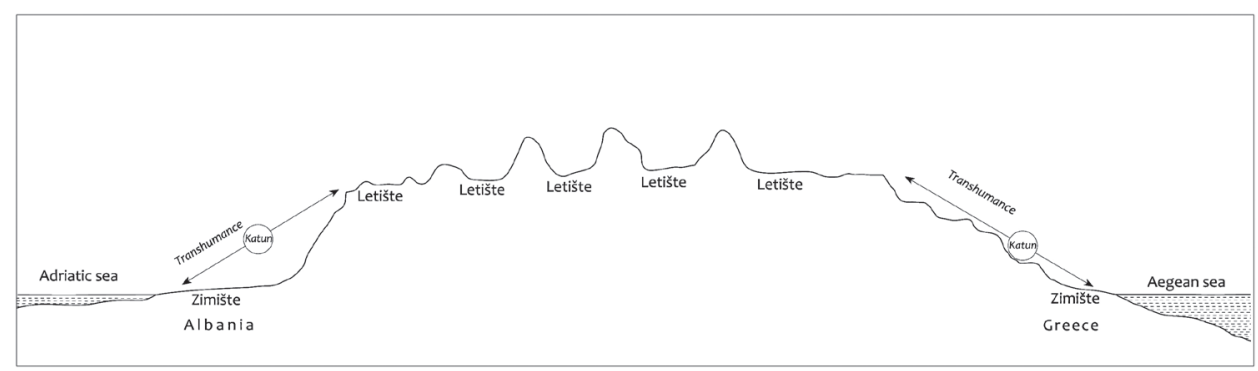

Map 3. Transhumance routes (author Miloš Luković).

al movements have been drastically reduced and transformed. On the other hand, the movements of real nomads and their livestock (for example, in the steppes of Central Asia) do not have an already established destination or a specific direction. This is why Marcu uses the term transhumance, and rejects the term nomadism as being inadequate for the seasonal movement of livestock breeders in the Balkans. His arguments have been accepted by Serbian historians and ethnologists, such as Bohumil Hrabak, Nikola Pavković, Slobodan Naumović etc. ${ }^{9}$ Acknowledging the arguments cited, I opt for the terms transhumance / transhumant movement of livestock breeders / transhumant type of livestock breeding to label various types of seasonal movement of livestock breeders in the Balkans, which have lasted for centuries, and still exist in a reduced form.

The transhumant type of livestock breeding always requires adequate organization, with the clearly defined roles of all participants. The forms of organization have changed over the centuries. ${ }^{10}$ In a medieval social system, only a stable organization could ensure an effective realization of the regime of seasonal movement of livestock breeders and fulfilment of all obligations they had towards their feudal lords. Medieval historical sources indicate that the katun constituted such an organization of transhumant livestock breeders. However, the medieval katun has long been a blurry concept for researchers (anthropologists, historians and others), and was confused with

${ }^{9}$ Medievalist Bogumil Hrabak (1927-2010) had on various occasions advocated the use of the term transhumance instead of the traditional and "incorrect" one nomadism, emphasising the existence of multiple types of transhumance; for a more detailed discussion, see Hrabak 2003, 37-43. Ethnologist Nikola Pavković and his younger colleague Slobodan Naumović consider the history of the transhumant animal husbandry to be insufficienlty studied, which leads to the poor understanding of the origins of certain institutions of the "clan organization". For a more detailed discussion see Pavković 2014, 145-146.

${ }^{10}$ Liviu Marcu has discussed various traditional forms of livestock breeding in the Balkans in the second half of the $19^{\text {th }}$ century, and concluded that "centuries of performing one activity - in this case, animal husbandry - dependant on historic circumstances, eventually led to a special form of legal and social organization: from a clan - in cases of constant extended transhumance - to a sedentery society, organized on a territorial basis - in the case of sheep farming in the mountains. The social and economic aspects of life were highly marked by the corporative organization. The role of the head of the community was strictly defined in various forms of transhumance, and the family exhibited patriarchal properties, to a greater or a lesser extent“. See Marcu 1976, 81-86. 


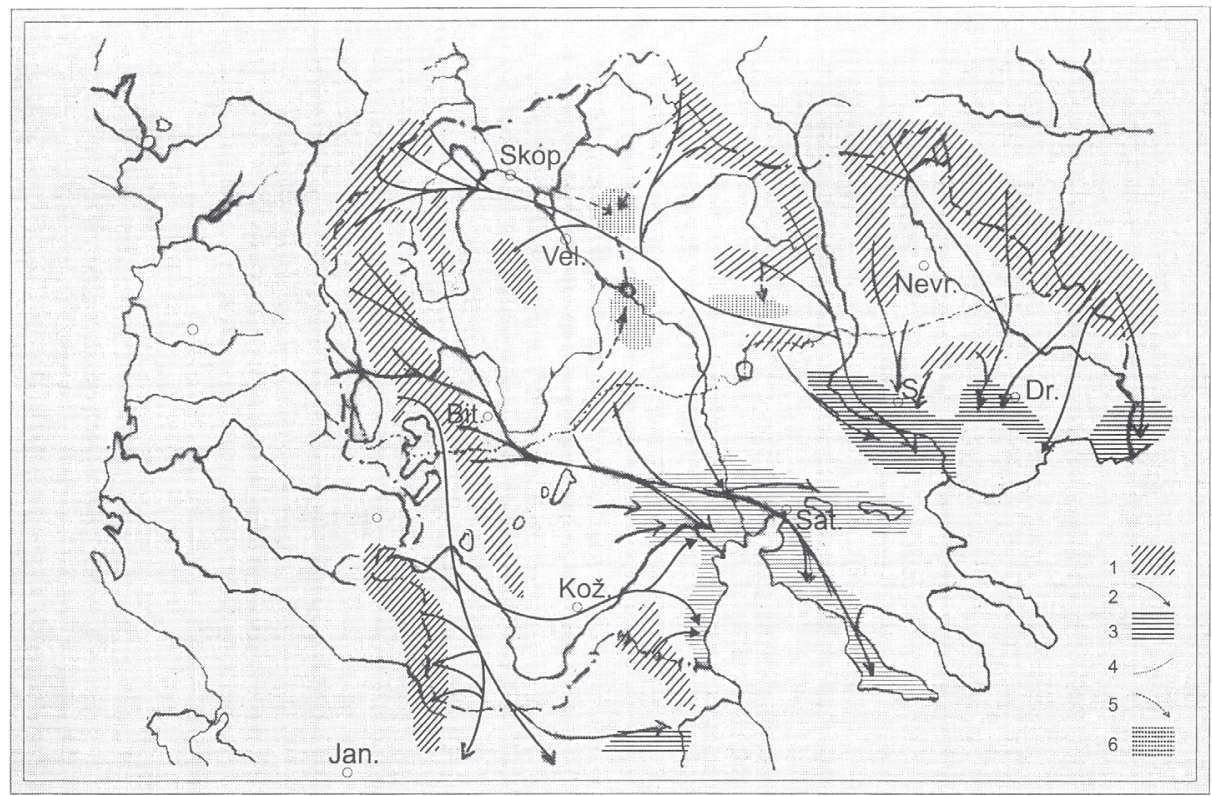

4. Transhumance in the central areas of the Balkans (Zdraveva and Todorovski 1997)

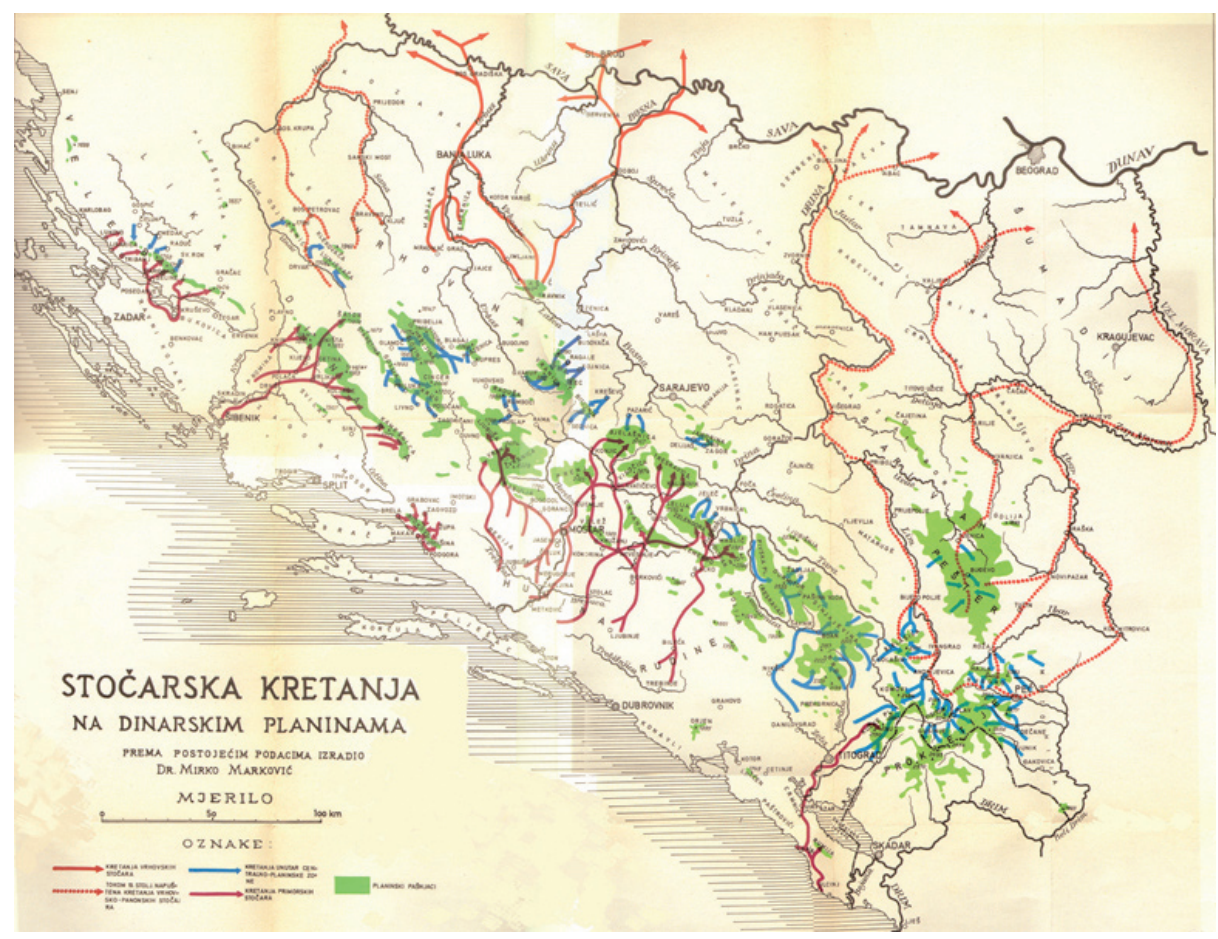

5. Transhumance in the western areas of the Balkans (Marković 1971) 
the modern meaning of the term. Today, the word katun in the Serbian and Bulgarian languages has the meaning of "a place in the mountains where livestock (mostly sheep) is grazed and milked in the summer"; in Romanian, cătun means "a small group of homesteads, smaller than a village"; in Albanian, katund means a "village";

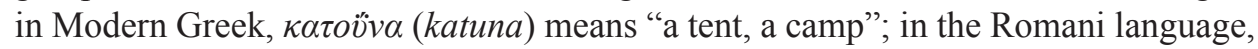
katuna means "a tent". 11

After much wandering in the $19^{\text {th }}$ century and the first half of the $20^{\text {th }}$, researchers came to understand, in the second half of the $20^{\text {th }}$ century, mostly thanks to medievalists and Ottomanists, ${ }^{12}$ that the medieval katun was the corporate organization of social and economic life of transhumant livestock breeders. It was the basic unit of livestock breeders' community, made up of several dozen households (kletištes) which were tied by kinship, sometimes with relatives in the female line (nephews, in-laws). ${ }^{13}$ After a certain period, it could divide and develop into new organizations of the same type (this is referred to as division of the katun). ${ }^{14} \mathrm{~A}$ katun was led by an elder (elected by their self-governing authority), and each katun had been called after its elder (for example: the "katun of Vukac Radičević") before the transhumant population became sedentary. ${ }^{15}$ In the western areas of the Balkans, the leader of the $k a$ tun was most often called katunar. Under the influence of Byzantine feudalism in the Serbian medieval state, in the areas that were closer to the Byzantine Empire, during

11 On contemporary meaning of the term katun and its etymology, see: Barić 1957, 230-231, Skok 1972, 64-65, Ajeti 1973, 203-215, Loma 2012, 102-103.

${ }^{12}$ For an exhaustive overview of Serbian medieval studies, see Ćirković and Mihaljčić, eds. 1999. For an overview of the development of Ottoman studies in Yugoslav and post-Yugoslav periods, see Smajić 2010.

${ }^{13}$ For more recent and more refined studies of the medieval katun see Sympozium on the Medieval katun (Simpozijum o srednjovjekovnom katunu) held in Sarajevo in 1961, with the idea that "katun, and medieval Vlachs in general, is a question of the utmost importance for Balkan studies. The solution to a series of other problems relies solely on the solution of this particular problem". Medievalists, orientalists and ethnologists shed light on the major aspects of the katun in the Middle Ages: its geographical characteristics, its structure and organization, its status in the sources from Dubrovnik, etc. The papers and proceedings from this Sympozium are still considered to be the classical literature on the medieval katun. Ethnologist Milenko Filipović (1902-1969) stated in his paper that katun in the Middle Ages referred to "a group of several families or households gathered around one elder, under whose authority they fulfilled their duties to the feudal lords and performed various activities pertaining to the livestock breeders' economy". He emphasized that " today's katuns are not the same as the medieval katuns". Based on the charters issued to the Serbian medieval monasteries during the Nemanjić era, Filipović concludes that a katun had between 5 and 80 households, and that it was not a community based exclusively on kinship, since it included both patrilateral and matrilateral kin. See Filipović 1963, 47-81.

14 On the basis of medieval and Ottoman sources, the medievalist Bogumil Hrabak analyzed katuns and their elders on the territory of Herzegovina in the period from the $13^{\text {th }}$ to the $15^{\text {th }}$ century. For further details, and especially on the division of a katun, see Hrabak 1997, 144-156.

${ }^{15}$ At the Sympozium on the Medieval katun in Sarajevo in 1961, medievalist Desanka Kovačević presented an extensive amount of data excerpted from the archives of Dubrovnik on the medieval katun and the Vlachs. She afforded special attention to the way the katuns were referred to in these documents: in the beginning they were designated by the names of their elders, and later by the territory they had settled in, without the elder's name, e.g.: "Vlachi in Biella in Drobgnaci“. See Kovačević 1963, 128-132. 
the $14^{\text {th }}$ century, there was a tendency for the king or the lord to appoint katunars, who

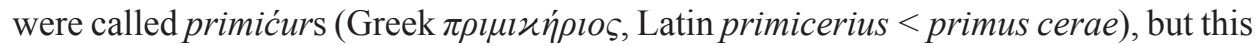
practice did not consistently spread in the western areas of the Balkans. A self-governing body - assembly, gathering (skupštinalzbor), was formed by the elders (katunars/primićurs) of the several katuns. However, in the central and western areas of the Balkans, the ruler would appoint a knez (under this name since the beginning of the $13^{\text {th }}$ century, before that the term sudija [judge] was used) as the leader of the group of several katuns, who was always one of the already existing katunars.

The institution of katunar/primićur and knez secured the self-governance of livestock breeders, and the knez was the link between the self-governance system and the central state government. Knez also acted as a judge for the members of all katuns under his control. The ruler would also appoint the vojvoda of a larger group of livestock breeders, also from among the katunars, who were responsible for recruiting (mobilization) soldiers in their groups, as well as for leading the warriors during military campaigns. ${ }^{16}$ Such an organization of livestock breeders based on katun (katun organization) would secure the social autonomy of the Vlach population within the feudal system of Christian states in the Balkans, including the medieval Serbian state.

In the regime of seasonal movement, the medieval Vlachs did not have permanent settlements for a long time. However, over time, in different historical circumstances, the winter residence of livestock breeders (mainly on monastic estates) became their permanent settlement - a village. In this way, livestock breeders became sedentary and, in addition to livestock breeding and caravan transport, they came to be engaged in farming, fruit growing, crafts, trade etc. This led to their mixing with the farming

16 Ottomanist Branislav Đurđev (1908-1993), first director of the Institute for Oriental studies in Sarajevo, began exploring Turkish archives in Ankara even before the Second World War. Since the very beginning he had afforded particular attention to the Vlach elders under the Osmanli rule. For further details, see Đurđev 1941, Đurđev 1948. At the Sympozium on the Medieval katun in Sarajevo in 1961 Đurđev raised the question of distinguishing the titles knez and primicur in the pre-Turkish period of the Middle Ages, since, until then, it had been widely accepted that "in the old Serbian state the functions of knez and primicur were one and the same in the Vlach organization". Relying on Christian sources from earlier periods and Ottoman sources from the $15^{\text {th }}$ century, Đurđev concluded that the katun had been headed by a katunar, often called primićur, whereas "knez was head both of his own katun and of the other primićurs", so "the title knez was higher in the katun hierarchy." Đurđev pointed out that the institution of knez had been introduced into the Vlach soceity under the Christian feudal influence, whereas the title itself had been taken from the "Slavic social organization". Medievalist Miloš Blagojević (19302012), established a precise chronology of the usage of the titles primicur and knez with a clear definition of their functions in medieval Serbia and Bosnia in the $13^{\text {th }}$ and $14^{\text {th }}$ centuries. In his opinion, the title $k n e z$ was introduced into the Nemanjić state in the early $13^{\text {th }}$ century, following the development of its administration, and it was used, among other things, to refer to the heads of assemblies formed by several $\mathrm{ka}$ tuns (with several hundred Vlach households). The Vlach knez was designated by the official ruler from among the katun elders. During the $14^{\text {th }}$ century, under the Byzantine influence, the ruler of the Serbian state ( $k r a l j, c a r)$ would appoint the elders of certain katuns, i.e. primićurs. This "byzantization" of the state was, however, neither uniform nor complete, so the title primićur is rarely mentioned in the southeastern territories, even in those areas which would become a part of the Bosnian state in the $14^{\text {th }}$ century (today's Herzegovina and the north-western areas of Montenegro). For further details see Blagojević 2005, 47-75. 


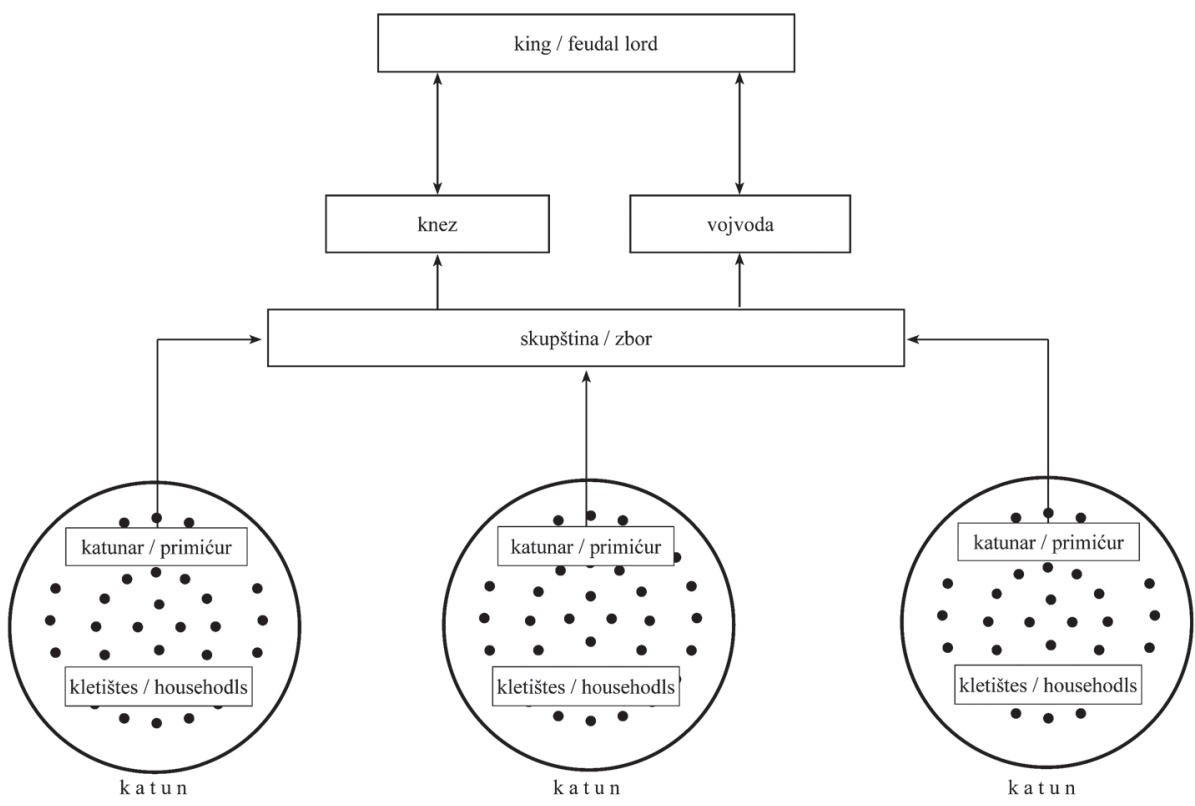

6. Katun organization (Luković 2013b)

population (of Slavic and other origin), who, in time, also accepted the transhumant type of livestock breeding, which became their main occupation. In fact, in this way the general process of mutual cultural, ethnic and linguistic permeation between the original livestock breeders and farmers unfolded gradually, which was also reflected in their spiritual culture. ${ }^{17}$

Transhumant livestock breeding in the Balkans in the Middle Ages greatly developed at a time when state borders were permeable, but also later, during the expansion of the Ottoman Empire, and came to a standstill in the period when the borders became stricter. ${ }^{18}$ The medieval Vlachs, as livestock breeders, were also horse

17 This complex and long process was described by many researchers on the medieval Vlachs. Cf. Filipović 1963, 50-58, Đurđev 1963, 153 -161, Luković 2012, 162-167, Luković 2013a, 412-413, Luković 2013b, 27-28.

18 This fact was repeatedly pointed out by the ethnologist and historian Aleksandar Matkovski (1922-1992), who studied "nomadic and semi-nomadic animal husbandry in Macedonia from the $14^{\text {th }}$ to the $19^{\text {th }}$ centuries." See Matkovski 1996, 7-12. I also want to emphasize the fact that the span and intensity of seasonal movements of the livestock breeders in the Balkans was dependant not only on natural conditions but also on current social and political circumstances, such as the changes of state borders during the Middle Ages and the period of Ottoman rule. I afforded special attention to the situation after the Balkan wars 1912-1913 and the establishment of new borders in the Balkans, which led to a drastic halt of the seasonal movements (e.g. from the mountains along the border between Macedonia and Albania towards the Aegean coast), or, at least, to their reduction to routes which remained within the newly developed state borders. See Luković 2013, 46-54). 
breeders. They used horses for their activities, but also for the long-distance caravan transport of goods (primarily salt), thus fulfilling their obligations towards their feudal lords.

\section{ZAKON VLAHOM IN THE CHARTERS ISSUED TO SERBIAN MEDIEVAL MONASTERIES}

Although transhumance and katun are often referred to in medieval Balkan sources, there were no regulations in medieval Balkan states (including Serbia) which would regulate the status of Vlachs as livestock breeders in a uniform manner. In the medieval Serbian state, regulations relating to Vlachs usually occur in the donation charters by which the ruler gave a grant of land to a monastery or, occasionally, in provisions of the agreements concluded between the Serbian state and the Republic of Ragusa (Dubrovnik), which was a significant trading power in the Balkan Peninsula. ${ }^{19}$ It should be emphasized, as a general remark, that among the surviving documents, royal charters (a total of 165) constitute the most numerous and the most important legal source for the history of medieval Serbia. ${ }^{20}$

But, when issuing charters to monasteries, the Serbian rulers had no intention to regulate the rights and obligations of the dependent population on, what we would call today, a national scale, including the Vlachs as livestock breeders. In fact, there were no prerequisites for such a thing: there was neither a unified fiscal system nor a central land register. The monastic charters specify the obligations of the dependent persons on the monastic land, including the Vlachs as livestock breeders, in the form of brief norms (rules) called zakon (which may be translated as "lex" or "law"). Although the norms relating to the Vlachs were supposed to meet the particular needs of a particular monastery or a church, their content is basically the same in many charters, and their prototypes were the charters of the monastery of Studenica (late $12^{\text {th }}$ century)

${ }^{19}$ In his seminal work from 1879 Die Wlachen und Maurowlachen in den Denkmälern von Ragusa (Vlachs and Maurovlachs in Ragusan documents) young Konstantin Jireček (1854-1918) showed that the Dubrovnik archives were an invaluable, yet at the time still unexplored, source for the study of medieval Vlachs. In preparing his article he also drew on historic sources that had previously been published by famous researches at the time, such as Pavel Šafařik, Alexandru Hâjdeu, Đura Daničić, Franz Miklosich, Medo Pucić, Ivan Črnčić, Franjo Rački, Šime Ljubić, Vatroslav Jagić and others. Jireček’s work was groundbreaking in many ways. Although the Ragusan sources referred only to the Vlachs in the Ragusan hinterland ("in the Adriatic area"), Jireček delimitation of the most important areas of research was applicable to the study of medieval Vlachs in general. These areas are: 1) regional habitats and types of Vlach settlements; 2) "nomadic" way of life of the Vlachs; 3) Vlachs as caravan traders; 4) Maurovlachs in Ragusan and Venitian documents; 5) Vlachs of the transdanubian Valachia. Moreover, the very contents and organization of his paper hinted at the subsequent areas of interest for future researchers of the medieval Vlachs: one would focus on the transhumant lifestyle of the Vlachs, another on their role as caravan traders; one would be centered on their social status and their role in a broader political context, another on the process of their assimilation, etc. For the Serbian translation of this paper, see Jireček 1959, 191-204.

${ }^{20}$ As pointed out by the medievalist Nebojša Šarkić, see Šarkić 1995, 9. 
and Mileševa (mid-13 $3^{\text {th }}$ century). Moreover, in three monastic charters dating from the first half of the $14^{\text {th }}$ century the norms relating to the Vlachs are grouped under one heading: Zakon Vlahom ("The Law on Vlachs"). ${ }^{21}$ These three charters were issued to the monasteries of:

1) Banjska: the Banjska or St Stephen Charter issued by king Milutin in 1313-16;

2) Hilandar: king Dušan donating to the monastery of Hilandar the church of St Nicholas near Vranje with the whole estate in 1343-45;

3) Prizren: Holy Archangels' Charter issued by Emperor Dušan in $1348-53 .{ }^{22}$

From various monastery charters it is evident that the majority of the Vlachs had identical obligations and that only some of these obligations were specific to certain monasteries. They depended, among other things, on the category and financial status of the Vlachs, who were divided into two basic categories: soldiers and chelators. The so-called chelators were more numerous but they were also a poorer social class than the soldiers. The Vlachs belonging to the soldier category also had military duties: they served as cavalrymen in their lord's military campaigns. However, regardless of these category differences, both soldiers and chelators guarded the caravans transporting salt and other goods on behalf of the monasteries. The most important dues of the Vlachs were paid in kind in two ways: by giving big tenth (tithe) or small tenth, a tribute system developed under Byzantine influence. The big tenth meant giving a tenth of all domestic animals (also called living tenth) reared by a household, plus two sheep every spring, as well as a special woollen cloth. By giving the big tenth, a household was exempted from paying any other dues to the monarch. Vlachs, who paid the small tenth, or the lesser tribute, were grouped into katuns, composed of fifty households, representing fiscal units. Instead of giving a "living tribute", each household of such a unit gave a sheep and a lamb, as well as a barren sheep; they were also burdened by various chores like shepherding duties (tending the monastery's flock of sheep), wool processing, manufacturing wool products, etc. The existence of the tenth as a form of paying the basic tribute by the population facilitated the introduction of the same tribute (ušur/öşur) in the Ottoman Empire later on. ${ }^{23}$

However, in medieval Serbia (like in other Balkan states), many issues concerning the herders' life were prescribed by common law, even after the more detailed codification of the law had taken place in the $14^{\text {th }}$ century. Stefan Dušan's realm incorporated large portions of former Byzantine territories ("Greek lands") in the Balkans, and he, now an emperor - identified with the universal Orthodox Christian empire had every intention to enact laws which would be enforced in the whole of his empire, an empire which was heterogeneous in legal, cultural and ethnic terms. The result of

${ }^{21}$ For norms in monastic charters containing Zakon Vlahom, see esp.: Blagojević 1979, 144-157, Blagojević 2009, 21-33.

${ }^{22}$ See map 1 for the location of these monastaries.

23 On the relation between desetak and ušur, see Miljković and Krstić 2009, 316. 
his state-building ambitions was a law code known as Dušan's Code (enacted in 1349 and supplemented in 1353). However, this Codex contains minimum regulations regarding livestock breeders, so their life was mostly organized according to common law. So article 82 of this Codex briefly regulates "should Vlachs or Albanians reside in a certain village, no others who would come immediately after them would be allowed to reside there; those who would forcefully disregard this would be fined accordingly“. This regulation of the Dušan's Code unequivocally testifies that the transhumant movement of the Vlach and Albanian livestock breeders existed in the large Serbian Empire. ${ }^{24}$

All of the tax liabilities of the Vlachs were significantly smaller than those of Serbian peasants (called meropahs or sebars) at the time. This is why Serbian peasants tended to become herders. This is evident from some monastery charters (monasteries of Banjska and Visoki Dečani), which prohibited peasants from "marrying into Vlachs" (taking a Vlach spouse), because by becoming a Vlach, one would become free from the feudal system and also from paying tributes. ${ }^{25}$

\section{KANUNS REGARDING VLACHS IN THE EARLY OTTOMAN TAX REGISTERS (DEFTERS)}

When the Ottomans had already forced their way into the Balkans (from the late $14^{\text {th }}$ century), a new kind of tax, the so-called "-Vlach ducat", was introduced, which largely replaced the tenth in the densely populated Vlach areas. The appearance of this type of tax was associated with the introduction of kharaj - a tribute that Christian states or feudal lords, as Ottoman vassals, had to pay to the Ottoman Empire. ${ }^{26}$ The annual tribute (which amounted to tens of thousands of ducats) was split among the population of a vassal territory, so that each Vlach household paid a tax of one ducat. In a certain way, this stimulated the survival of large herding families. ${ }^{27}$

${ }^{24}$ For a more detailed discussion, see Šarkić 1995, 39-42.

${ }^{25}$ For a more detailed discussion, see Šarkić 1995, 39-42.

${ }^{26}$ In 1890 Jireček's friend and contemporary Stojan Novaković (1842-1915), Serbian legal historian, philologist and statesman, published his book Selo, which was held in high esteem and abundantly used by Jireček in his Geschichte der Serben. I-II (Gotha 1911-1918), which has multiple Serbian translations. For Jireček's review of Selo see Jireček 1984, 271. Novaković discusses at length the settlements and status of a dependent population in the "old" (medieval) Serbian state, notably of farmers (meropahs) and livestock breeders (Vlahs and Arbanasins). In his opinion, Serbian authorities endeavoured to restrain the "eternal movement" of livestock breeders and bind them to the land. He interpreted one article of the charter issued to the monastery of Dečani accordingly: "A Serbian cannot marry a Vlach; if he does, his wife becomes a meropah" as: "A farmer cannot marry a daughter of a nomad, and if he does - he cannot leave the land and follow his wife as a livestock breeder, but his wife must settle with him in the farmer's village". Therefore, he claimed, the interpretation of this article in the view of ethnic segregation ("as if it were about Serbian or Romanian nationality"), as many researchers did, including Franz Miklosich, does not seem to be tenable. For more details, see Novaković 1965, 40, 189.

${ }^{27}$ For a more detailed discussion, see Hrabak 1997, 155-156. 


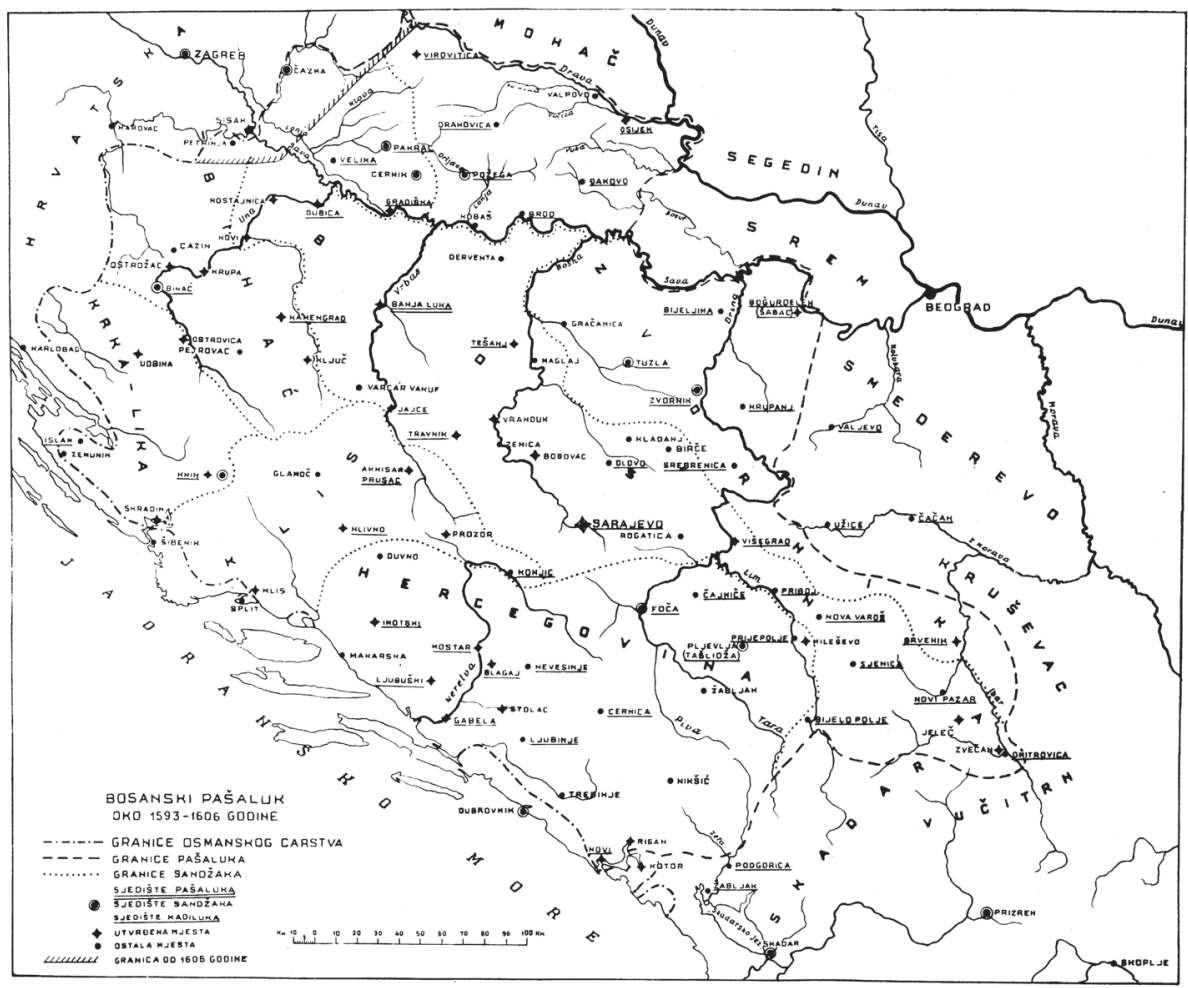

7. The Pashalik of Bosnia and sanjaks (Šabanović 1982)

Since the creation of the Ottoman Empire, the basic military and administrative unit was the sanjak or liva headed by the sanjak-bey. In conquering the Christian lands in the Balkans in the $14^{\text {th }}$ and $15^{\text {th }}$ century, the Ottoman state initially held certain lands and regions in a vassal status, and the sanjaks were formed following their definitive subjugation and termination of the vassal status. The smaller territorial unit within the sanjak was the nahiye. A nahiye usually coincided with the boundaries of the previous Christian unit - župa. Thus during the $14^{\text {th }}$ and $15^{\text {th }}$ centuries the following sanjaks were created: the so-called Pasha-sanjak (which included large portions of the eastern and central Balkans, with its seat in Edirne), and the sanjaks of Sofia, Manastır (Bitola), Köstendil (Kyustendil), Vidin, Vıçıtırın (Vučitrn), Prizren, Alacahisar (Kruševac), Smederevo, Dukagjin, Bosnia, Hersek (Herzegovina), Zvornik and İşkodra (Shkodër), and later others followed. The sanjaks formed part of larger territorial units called eyalets or beylerbeyliks, headed by a beylerbey (the beylerbey could also hold the Ottoman title of pasha, and in that case the elayet was also called a pashalik). By the time of the Ottoman conquest of Hungary there was only one Ottoman eyelet in the Balkans - the Rumelia Eyelet (until the beginning of the $15^{\text {th }}$ 
century its seat was in Edirne, and later in Sofia), and later the eyelets of Budin (Buda), Temeşvar (Timişoara), Eger (Eğri), Bosnia, Kanizsa (Kanije), Varat and Uyvar. ${ }^{28}$

In order to irrefutably conquer an area, or terminate its vassal status, the Ottomans would turn it into a sanjak. They would immediately categorize the population in the sanjak according to their income, so they could determine their tax obligations in accordance with the Sharia (Islamic law). This led to the creation of the Ottomans tax registers - defters. ${ }^{29}$ Some of these defters were cumulative (extensive tax records), and some were individual (also referred to as detailed books, since they individually listed the name of each taxpayer), meaning they differed in the level of detail. The defters for the European sanjaks from the $15^{\text {th }}$ and $16^{\text {th }}$ centuries are generally known and partly published. These early defters include brief terms of a regulatory nature kanun (kanûn). The regulations relating to the Vlachs are called kanûn-i eflak. Later, defters often appeared as codified collections (kanûn-name) of royal decrees ( $k a-$ nuns), which is related to the evolution of legislative practice in the Ottoman Empire. Historians have long asserted that these kanuns contained legal solutions and practices applied to the Vlachs in the territories previously conquered by the Ottomans ${ }^{30} \mathrm{All}$ Vlach tax obligations were always converted into silver coins (akcha /akçe) according to a fixed rate. If we compare individual sanjak defters of the period, we can see that the Vlach obligations were very similar. The Vlachs fulfilled their obligations in two ways: through households, and through katuns, composed of up to 50 households.

Thus, according to the defter for the Sanjak of Herzegovina for 1475-1477 (where Vlachs lived in great numbers), on Saint George's Day every Vlach household paid: one ducat (filuri), one sheep with a lamb (or 12 silver coins) and one ram (or 15 silver coins). Also, every katun (called jemat in defters - a Turkish name for this social unit) gave a total of 50 ducats, and also collectively two rams (or 60 silver coins) and one tent (cherga) made from goat skin (or 100 silver coins). And in times of war, every ten households in a katun had to send one armed horseman (cavalrymen) to take part in the military campaign. Only after they had met all these obligations, were the Vlachs exempted from any other dues. ${ }^{31}$

The Vlachs from the neighbouring sanjaks (Sanjaks of Bosnia and Zvornik, and even from the geographically more remote Sanjak of Smederevo) had similar obligations to those of Herzegovina. The defter for the Sanjak of Smederevo for 14761477 registers a large number of Vlachs households, and many of these came from

\footnotetext{
${ }^{28}$ As pointed out by the medievalist Ema Miljković-Bojanić in her book on the sanjak of Smederevo from 1476 to 1560: Miljković-Bojanić 2004, 230.

${ }^{29}$ For an overview of Ottoman defters for central and western areas of the Balkans published up to 2008, see the book of Tatjana Katić on the defter of the sanjak of Prizren from 1571: Katić 2010, 5-8. The defter of the sanjak of Herzegovina from 1585 was edited by Ahmed Aličić and published in 2014, see Aličić 2014.

${ }^{30}$ As pointed out by several Ottomanists: Begović 1951/1952, 67-84, Inaldžik 1953, 23-55, Đurđev et alt, eds. 1957, 7-18, Miljković and Krstić 2009, 301.

31 The defter of the sanjak of Herzegovina 1475-1477 was edited by Ottomanist Ahmed Aličić. On Vlach legal obligations see esp. Aličić 1985, V, IX, 26.
} 
Herzegovina shortly before the defter was compiled. Unlike Herzegovina, in the area of Smederevo there are no high mountains, so this sanjak had no geographical conditions for transhumance; even so, here too a katun was composed of fifty households. ${ }^{32}$ Households paid their tribute at Christmas, while on Saint George's Day they gave a sheep with a lamb (or 20 silver coins). In Sanjak of Smederevo, katun as a whole had somewhat different obligations compared to that of Herzegovina. Here, every five households had to send one armed horseman to war, a practice adopted from the former feudal state (Serbian Despotate).

Kanuns from the Ottoman defters tell us that the Vlachs collectively adopted the Ottoman system, retaining their previous social organization and self-government. ${ }^{33}$ It was actually the realization of Ottoman politics, with the intention of strengthening Ottoman feudalism (sipahi/timar system) and military presence. ${ }^{34}$ But in the first half of the $16^{\text {th }}$ century, when the Turks crossed the River Sava and River Danube and conquered a greater part of Hungary, former sanjaks (Smederevo, Vidin, Kruševac, Zvornik, Bosnia) lost their borderland position. Thus the status that Vlachs previously enjoyed (adet-i eflakiyye) was abolished in these areas, but was reintroduced in the sanjaks of Vidin and Bosnia in 1550. ${ }^{35}$

32 Ottomanist Dušanka Bojanić afforded special attention to Ottoman kanuns for the areas of Smederevo, Kruševac and Vidin in the $15^{\text {th }}$ and $16^{\text {th }}$ centuries. See Bojanić 1974, 13, 27-35. On Vlach legal obligations in the sanjak of Smederevo in the $15^{\text {th }}$ and $16^{\text {th }}$ century, see Miljković-Bojanić 2004, 239240 .

33 At the sympozium on the Medieval katun in Sarajevo in 1961 Branislav Đurđev gave a detailed account of the process he called the territorialization of the katuns, emphasizing that it "took centuries", and that "it was not a uniform process but one that was completed through a series of local processes". He pointed out that "the essence of the process lies in the partial or total reorientation of livestock breeders to farming". He hypothesized that those katuns which were under the jurisdiction of the Serbian medieval monasteries went through this process more quickly than those who fell under the category of "imperial Vlachs" (which remain a bit mysterious, although we can assume that they were not as tightly bound to a particular territory, i.e. that their seasonal routes between summer and winter pastures were longer). Đurđev reiterated his earlier claim that the "material from the Turkish defters from the second half of the $15^{\text {th }}$ and the first half of the $16^{\text {th }}$ centuries provided new evidence and explanations for that process". However, Đurdev pointed out that the mass Vlach colonization of lowland regions (closer to the River Sava and River Danube) under the control of the Ottoman authorities in the late $15^{\text {th }}$ and early $16^{\text {th }}$ centuries brought about a change in the Vlach social autonomy. Since these new geographical regions provided no conditions for the transhumant movement of livestock breeders, the Vlachs turned to farming and became sedantery. Thus the katuns became territorialized, that is, the Vlach self-governance became tied to a certain territory, which laid the foundation for the establishment of a new form of territorial self-governance - knežina. A similar process took place in the Dinarides, where, since there were conditions for transhumance, it gave rise to another form of territorial autonomy - pleme (clan). For more details see Đurđev 1963, 142-169. Medievalist Milan Vasić elucidated the establishment of knežinas in his study on Vlachs in the sanjak of Zvornik in the $16^{\text {th }}$ century; see Vasić 1959, 247-278. For more details on the origins of institutions of self-governance in knežinas and plemes, see: Luković 2013b, 20-29, Luković 2014, $131-138$.

34 Šabanović 1964, 144.

35 See: Matkovski 1996, 61-63, Miljković-Bojanić 2004, 239-240, Miljković 2010, 66-67. 


\section{BIBLIOGRAPHY}

Ajeti, Idriz. 1973. "Prilog proučavanju davnašnjih arbanasko-južnoslovenskih jezičkih odnosa.” Godišnjak akademije nauka Bosne i Hercegovine XI. Sarajevo: 203-215.

Aličić, Ahmed S. 1985. Poimenični popis Sandžaka vilajeta Hercegovina. Sarajevo: Orijentalni institut.

Aličić, Ahmed. 2014. Opširni katastarski popis za oblast Hercegovu iz 1585. godine. I-II. Sarajevo: Dobra knjiga.

Barić, Henrik. 1957. "Katun.” In Enciklopedija Jugoslavije. Tom 5, gl. red. Miroslav Krleža, 1957, 230 -231. Lekskografski zavod Federativne Narodne Republike Jugoslavije.

Begović, Mehmed. 1951/1952. "Tragovi našeg srednjovekovnog prava u turskim pravnim spomenicima.” Istoriski časopis 3. Beograd: 67-84.

Blagojević, Miloš. 1979, “Zakon svetoga Simeona i svetoga Save.” In Sava Nemanjić - Sveti Sava, istorija i predanje, red. Vojislav Đurić, 144-157. Beograd: Srpska akademija nauka I umetnosti.

Blagojević, Miloš. 2005. "Vlaški knezovi, primićuri i čelnici u državi Nemanjića i Kotromanića (13-14. vek).” In Spomenica Milana Vasića, red. Rade Mihaljčić, 43-75. Banja Luka: Akademija nauka i umjetnosti Republike Srpske.

Blagojević, Miloš. 2009. "Posebni zakoni na manastirskim vlastelinstvima." In Srednjovekovno pravo u Srba u ogledalu istorijskih izvora. Zbornik sa naučnog skupa održanog 19-21. marta 2009, red. Sima Ćirković i Kosta Čavoški, 21-33. Beograd: Srpska akademija nauka i umetnosti.

Bojanić, Dušanka. 1974. Turski zakoni i zakonski propisi iz XV i XVI veka za smederevsku, kruševačku i vidinsku oblast. Beograd: Istorijski institut,

Brodel, Fernan. 2001. Mediteranski svet u doba Filipa II 1-2. Beograd: Geopolitika.

Cvijić, Jovan. 1966. Balkansko poluostrvo i južnoslovenske zemlje. Beograd: Zavod za udžbenike Socijalističke Republike Srbije.

Ćirković, Sima. 1995. Srbi u srednjem veku. Beograd: Izdavačka zadruga Idea.

Ćirković, Sima i Rade Mihaljčić, eds. 1999. Leksikon srpskog srednjeg veka, Beograd: Knolidge 1999.

Dragomir, Silviu. 1921/1922. "Vlahii din Serbia în sec. XII-XV.” Anuarul Institutului de Istorie Naţională. Cluj: 279-299.

Dunăre, Nicolae. 1976. „Typologie pastorale traditionnelle Sud-Est Européenne.“ In Odredbe pozitivnog zakonodavstva i običajnog prava o sezonskim kretanjima stočara u jugoistočnoj Evropi. Zbornik radova sa međunarodnog naučnog skupa održanog 6. i 7. novembra 1975. u Beogradu, red. Vasa Čubrilović, 189-212. Beograd: Balkanološki institut Srpske akademije nauka i umetnosti.

Đurđev, Branislav. 1941. "Nešto o vlaškim starješinama pod turskom upravom." Glasnik Zemaljskog muzeja u BiH, god. LII, sv. 1, Sarajevo: 49-67.

Đurđev, Branislav. 1948. “O knezovima pod turskom upravom.” Istoriski časopis 1-2. Beograd: $132-157$.

Đurđev, Branislav. 1963. "Teritorijalizacija katunske organizacije do kraja XV vijeka (katun - knežina pleme).” In: Simpozijum o srednjovjekovnom katunu održan 24. i 25. novembra 1961. g., red. Milenko Filipović, 143-169. Sarajevo: Naučno društvo Bosne i Hercegovine.

Đurđev, Branislav et alt, eds. 1957. Kanuni i kanun name za Bosanski, Hercegovački, Zvornički, Kliški, Crnogorski i Skadarski sandžak. Sarajevo: Orijentalni institut.

Filipović, Milenko. 1963. "Struktura i organizacija srednjovekovnih katuna." In Simpozijum o srednjovjekovnom katunu održan 24. i 25. novembra 1961. g., red. Milenko Filipović, 45-112. Sarajevo: Naučno društvo Bosne i Hercegovine.

Hrabak, Bogumil. 1997. "Čelnici stočarskih zajednica u istočnoj Hercegovini u XIII-XIV veku." In Zbornik za istoriju Bosne i Hercegovine 2, red. Milorad Ekmečić, 139-172. Beograd: Srpska akdemija nauka i umetnosti.

Hrabak, Bogumil. 2003. Iz starije prošlosti Bosne i Hercegovine. Knj. II. Beograd: Arhivar.

Inaldžik, Halil. 1953. "Od Stefana Dušana do Osmanskog carstva." Prilozi za orijentalnu filologiju III-IV. Sarajevo: 23-55. 
Inaldžik, Halil. 1974. Osmansko carstvo. Klasično doba. Beograd: Srpska književna zadruga.

Jireček, Konstanin. 1959. "Vlasi i Mavrovlasi u dubrovačkim Spomenicima." In Zbornik Konstantina Jirečeka. I, red. Mihailo Dinić, 191-204. Beograd: Srpska akademija nauka i umetnosti.

Jireček, Konstantin. 1984. Istorija Srba. Knjiga II, preveo Jovan Radonić, treće izdanje. Beograd: Slovo ljubve.

Katić, Tatjana. 2010. Opširni popis Prizrenskog sandžaka iz 1571. godine. Beograd: Istorijski institut.

Kovačević, Desanka. 1963. "Srednjovjekovni katun po dubrovačkim izvorima." In Simpozijum o srednjovjekovnom katunu održan 24. i 25. novembra 1961. g., red. Milenko Filipović, 121-140. Sarajevo: Naučno društvo Bosne i Hercegovine 1963.

Loma, Aleksandar. 2012. Toponimija Banjske hrisovulje. Beograd: Srpska akademija nauka i umetnosti.

Luković, Miloš. 2010. "Prvi turski popisi i početna teritorijalna organizacija turske vlasti na Kosovu i Metohiji." In Kosovo i Metohija u civilizacijskim tokovima. Zbornik radova sa međunarodnog naučnog skupa u Kosovskoj Mitrovici, 8-11. oktobar 2009. Knjiga 3. Istorija. Istorija umetnosti, gl. urednik Dragi Maliković, 125-141. Kosovska Mitrovica: Filozofski fakultet.

Luković, Miloš. 2012. "Transhumantní migrace pastevců v centrálních a západních oblastech Balkánu." In Zygmunt Kłodnicki et alt. Tradiční agrárni kultura v kontextu společenského vývojestředni Evropy a Balkánu, 145-196, 250-251. Brno: Masarykova univerzita, Filozofická fakulta - Ústav evropske etnologie.

Luković, Miloš. 2013. "Balkanlarda Besicilerin Transhumance Hareketleri ve Balkan Savaşları'nın Besicilerin Mevsimsel Hareketlerine Etkisi." History Studies. International Journal of History Volume 5/Issue 6. Ankara (Turkey), Edinburg - Texas (USA): 41-58.

Luković, Miloš. 2013a. "Katun a katunová organizace středověkých Vlachů v centrálních a západních oblastech Balkánu." Slovanský přehled. Review for History of Central, Easternan and Southeastern Europe 5. Praha: 387-416.

Luković, Miloš. 2013b. "Knežinska i plemenska samouprava kod Srba: poreklo institucija.“ Naša prošlost 14. Kraljevo: 9-30.

Luković, Miloš. 2014. "Valašské právo jako základ valašské kolonizace - komparace s vlašským právem na Balkáně.” In Valašsko. Historie a kultura, eds. Svatava Urbanová, Lumír Dokoupil, Jakub Ivánek, 131-139. Ostrava: Filozofická fakulta Ostravské university - Valašské muzeum v př́rodě v Rožnově pod Radhoštěm.

Marcu, Liviu. 1976. "Formes traditionnelles d'élevage pastoral et systèmes d'organisation chez les Vlaques balkaniques." In Odredbe pozitivnog zakonodavstva i običajnog prava o sezonskim kretanjima stočara u jugoistočnoj Evropi. Zbornik radova sa međunarodnog naučnog skupa održanog 6. $i$ 7. novembra 1975. u Beogradu, red. Vasa Čubrilović, 67-86. Beograd: Balkanološki institut Srpske akademije nauka i umetnosti.

Marković, Mirko, 1971. "Stočarska kretanja u Dinarskim planinama." Zbornik za narodni život i običaje Južnih Slavena 45. Zagreb: 523-549.

Matkovski, Aleksandar. 1996. Nomadskoto stočarstvo vo Makedonija od XIV do XIX vek. Skopje: Makedonska akademija na naukite i umetnostite.

Miljković, Ema. 2010. "Vlasi u domaćoj istoriografiji (1960-2010).” Braničevski glasnik 7. Požarevac: $5-22$.

Miljković, Ema and Aleksandar Krstić. 2009. “Tragovi srpskog srednjovekovnog prava u ranim osmanskim kanunima i kanunnama." In Srednjovekovno pravo u Srba u ogledalu istorijskih izvora. Zbornik sa naučnog skupa održanog 19-21. marta 2009, red. Sima Ćirković i Kosta Čavoški, 301-319. Beograd: Srpska akademija nauka i umetnosti.

Miljković-Bojanić, Емa. 2004. Smederevski sandžak 1476-1560. Zemlja, naselja, stanovištvo. Beograd: Istorijski institut.

Novaković, Stojan. 1965. Selo, treće izdanje. Beograd: Srpska književna zadruga.

Pavković, Nikola F. 2014. Studije i ogledi iz pravne etnologije. Beograd: Srpski genealoški centar.

Skok, Petar. 1928. "Iz rumunske literature o balkanskim Vlasima. III-IV.” Glasnik Skopskog Naučnog Društva 3. Skoplje: 293-308. 
Skok, Petar. 1972. Etimologijski rječnik hrvatskoga ili srpskog jezika. Knjiga druga. K-poni. Zagreb: Jugoslavenska akademija znanosti i umjetnosti.

Smajić, Ramiza. 2010. "Pravci razvoja osmanistike u jugoslovenskom i postjugoslovenskom periodu." In Naučno djelo Branislava Đurđeva. Zbornik radova sa međunarodnog okruglog stola održanog u Sarajevu 4. decembra 2009, red. Dževad Juzbašić, 93-100. Sarajevo: Akademija nauka Bosne I Hercegovine.

Stojanovski, Aleksandar. 1973. "Administrativno-teritorijalnata podelba na Makedonija pod osmanskata vlast do krajot na XVII vek." Glasnik na Institutot za nacionalna istorija 2. Skopje: 129-145.

Šabanović, Hazim. 1964. Krajište Isa-bega Ishakovića. Zbirni katarstarski popis iz 1455. godine. Uvod, turski tekst, prevod i komentari Hazima Šabanovića. Sarajevo: Orijentalni institut.

Šabanavić, Hazim. 1982. Bosanski pašaluk, drugo izdanje. Sarajevo: Svjetlost.

Šarkić, Srđan. 1995. Srednjovekovno srpsko pravo. Novi Sad: Marica srpska.

Šehić, Denis, and Demir Šehić. 2007. Istorijski atlas sveta za škole i kuću. Beograd: Monde Neuf.

Vasić, Milan. 1959. "Knežine i knezovi timarlije u Zvorničkom sandžaku u XVI vijeku." Godišnjak Istoriskog društva Bosne i Hercegovine X. Sarajevo: 247-278.

Zdraveva, Milka and Gligor Todorovski. 1997. Nomadskoto stočarstvo vo Makedonija vo XIX vek do 1918. Skopje: Makedonska akademija na naukite i umetnostite.

Zirojević, Olga. 1974. Tursko vojno uređenje u Srbiji 1459-1683. Beograd: Istorijski institut. 